\title{
PENGUASAAN SHIEKIBUN PADA MAHASISWA TAHUN MASUK 2017 PROGRAM STUDI PENDIDIKAN BAHASA JEPANG UNIVERSITAS NEGERI PADANG
}

\author{
Afrinawati ${ }^{1}$, Meira Anggia Putri ${ }^{2}$ \\ Program Studi Pendidikan Bahasa Jepang ${ }^{1}$ (Jurusan Bahasa dan Sastra Inggris, Fakultas \\ Bahasa dan Seni, Universitas Negeri Padang) \\ Program Studi Pendidikan Bahasa Jepang ${ }^{2}$ (Jurusan Bahasa dan Sastra Inggris, Fakultas \\ Bahasa dan Seni, Universitas Negeri Padang) \\ Email Penulis : afrinawati904@gmail.com
}

\begin{tabular}{ll}
\hline Sejarah Artikel \\
\hline Submit $\quad: 2020-05-05$ \\
Diterima $: 2020-06-18$ \\
Diterbitkan $: 2020-07-20$
\end{tabular}

Kata Kunci:

Penguasaan, Shiekibun

\begin{abstract}
Abstrak
This study discusses the mastery of Shiekibun in 2017 students of Japanese language study programs at Padang State University. The purpose of this study was to determine the Shiekibun mastery of 2017 students entering the Japanese Language Study Program at Padang State University. This type of research used in this research is quantitative research with descriptive methods. The population in this study were students entering 2017 Japanese Language Education Study Program, Padang State University, amounting to 56 people. The sample in this study amounted to 30 people. The data of this study are the Shiekibun mastery test scores for 2017 students entering the Japanese Language Study Program at Padang State University. Based on the results of the research carried out it can be concluded that the mastery of student Shiekibun in 2017 in general is in the qualification "pretty good" with an average of 66.8 .
\end{abstract}

\section{PENDAHULUAN}

Bahasa merupakan komponen penting dalam berkomunikasi bagi kehidupan manusia. Sebagai alat komunikasi utama, bahasa dapat berfungsi untuk menyampaikan ide, gagasan atau pokok pikiran bagi manusia. Bahasa tersebut dapat berupa lisan, tulisan maupun dengan isyarat. Salah satu bahasa yang cukup banyak dipelajari di Indonesia karena keunikannya adalah bahasa Jepang. Seperti yang dikutip dari Danasasmita (dalam Rohman 2015: 7) pada tahun 2004 tercatat sebanyak 432 instansi tingkat pendidikan menegah dan 78 universitas mengajarkan bahasa Jepang. Bahasa Jepang adalah bahasa yang unik, keunikan bahasa Jepang dapat dilihat dari karekteristik bahasanya, baik dari segi huruf, kosakata, kalimat dan gramatikalnya.

Salah satunya dari segi kosakata. Menurut Sudjianto (2009:98) kosakata dapat diklasifikasikan berdasarkan pada cara-cara, standar, atau sudut pandang apa kita melihannya. Misalnya berdasarkan karakteristik gtramatikalnya terdapat kata-kata yang tergolong doushi (verba), i-keyoushi atau ada yang menyebutnya keiyoushi

${ }^{1}$ Mahasiswa Prodi Pendidikan Bahasa Jepang FBS UNP Iulus pada Desember 2019

2 Dosen Prodi Pendidikan Bahasa Jepang FBS UNP 
(ajektiva-i), na-keiyoushi atau ada yang menyebutnya keiyoudoshi (ajektiva-na), meishi (nomina), rentaishi (prenomina), fukushi (adverbial), kandoushi (interjeksi), setsuzokushi (konjungsi), jodoushi (verba bantu), dan joshi (partikel). Dari klasifikasi kosakata di atas, salah satu kelas kata yang sering digunakan adalah doushi (verba). Doushi dalam bahasa Indonesia yang dikenal dengan istilah kata kerja, doushi merupakan salah satu kelas kata dalam bahasa Jepang yang digunakan untuk menyatakaan akivitas, keadaan atau keadaan sesuatu.

Doushi dapat berkonjugasi, salah satu konjugasi verba dalam bahasa Jepang adalah dalam bentuk Shieki (kausatif). Shieki dalam bahasa Jepang merupakan salah satu bentuk kata kerja yang bermakna menyuruh atau membuat seseorang melakukan suatu aktivitas. Menurut Koyama (2001 : 140) shieki dalam gramatikal bahasa Jepang menunjukkan makna pemaksaan, atau pemberian izin. Shieki dibentuk dari verba transitif maupun intransitif. Kemunculan verba kausatif ditandai dengan perubahan verba transitif maupun intransitif menjadi 〜せる( seru) atau 〜させる ( saseru) yang mengandung makna pemaksaan, pemberian izin, seseorang melakukan sesuatu aktivitas. Menurut Sutedi (2007 : 132) perubahan kata kerja bentuk kamus ke dalam shieki, ketentuannya sebagai berikut. 1) untuk kata kerja kelompok I yang berakhiran suara/huruf $u$ (う) diganti dengan わせる(waseru) sedangkan yang berakhiran suara/huruf $t s u(つ), k u(く), g u(く ゙), m u(む), n u(ぬ)$, $b u$ (ぶ), dan $s u$ (す), jika ditulis dengan huruf alfabet, bunyi U-nya diganti dengan aseru (あ-せる). 2) untuk kata kerja kelompok II, akhiran ru (る) diganti dengan saseru (させる). 3) untuk kata kerja kelompok III, suru (する) menjadi saseru (させ る : menyuruh melakukan), dan kuru (くる) menjadi kosaseru (こさせる : menyuruh datang).

Kalimat yang menggunakan verba bentuk shieki disebut shiekibun. Dalam Nihongo Bunkei Jiten (1989 : 129) shiekibun yaitu suatu perintah atau instruksi dari seseorang sehingga orang lain melakukan suatu perbuatan, tetapi ketika digunakan dalam hal sebenarnya menunjukkan makna yang lebih luas seperti menyuruh, instruksi, membiarkan, mengijinkan, dan sebagainya. Dapat disimpulkan bahwa shiekibun yaitu kalimat yang menyatakan seseorang yang menyuruh atau membuat orang lain melakukan sesuatu. Sebagai contoh kalimat 先生は私に本を読ませる (sensei wa watashi ni hon o yomaseru) yang berarti "saya disuruh membaca buku oleh guru”. Pada kalimat diatas, kata 読ませる(yomaseru) yang berarti (disuruh membaca) berasal dari kata 読む(yomu), huruf む $(m u)$ mengalami perubahan ま (ma) dan dibubuhkan せる (seru).

Pada penelitian Norman (2014) yang berjudul "Analisis Kesalahan Penggunaan Shieki Pada Mahasiswa Program Studi S1 Sastra Jepang Angkatan 2011 Universitas Brawijaya". Ia menyimpulkan bahwa jenis kesalahan yang ditemukan yaitu: (1) menganalogi: Pada bagian partikel, responden masih rancu dengan penggunaan $n i$ dan wo pada kalimat shieki dan kalimat futsukei, pada bagian verba, responden masih bingung antara pengonjugasian verba shieki, kanoukei, dan ukemi; (2) tekstual: Responden menganggap beberapa kalimat dalam soal merupakan bentuk perintah pasif, aktif, atau perintah; (3) penerimaan: responden tidak membaca soal secara keseluruhan karena soal dianggap terlalu panjang; (4) salah ungkap: responden yang 
sebenarnya ingin menjawab kosaseru malah menjawab korareru; (5) guru: beberapa responden menganggap saat diajar shieki, pengajar tidak menjelaskan secara terperinci dan kurang diberi latihan.

Berdasarkan wawancara kepada mahasiswa tahun masuk 2017 Program Studi Pendidikan Bahasa Jepang Universitas Negeri Padang tentang pelajaran shiekibun, diketahui bahwa pembelajaran shiekibun cukup sulit, khususnya pada perubahan gramatikal dan makna kata. Mahasiswa sulit membedakan penggunaan shiekibun tersebut pada verba transitif atau intransitif. Peneliti juga telah mewawancarai dosen terkait pembelajaran shiekibun mahasiswa tahun masuk 2017 Program Studi Pendidikan Bahasa Jepang Universitas Negeri Padang. Senada dengan mahasiswa salah seorang dosen yang mengajar mahasiswa tahun masuk 2017 Program Studi Pendidikan Bahasa Jepang Universitas Negeri Padang mengatakan bahwa dalam pembelajaran shiekibun mahasiswa kebanyakan kurang paham dalam penggunaan kalimat, menyebabkan mahasiswa kurang berani/ percaya diri membuat kalimat.

\section{METODE PENELITIAN}

Jenis penelitian ini yaitu penelitian kuantitatif, karena data yang diteliti berupa angka-angka. Data dalam penelitian ini adalah nilai dari Penguasaan Shiekibun Mahasiswa Tahun Masuk 2017 Prodi Pendidikan Bahasa Jepang Universitas Negeri Padang. Metode penelitian yang digunakan dalam penelitian ini adalah metode deskriptif. Populasi dalam penelitian ini yaitu mahasiswa tahun masuk 2017 Prodi Pendidikan Bahasa Jepang Universitas Negeri Padang yang berjumlah 56 orang. Adapun sampel dalam penelitian ini yaitu sebanyak 30 orang. Teknik pengambilan sampel dalam penelitian ini yaitu menggunakan teknik random sampling. Teknik random merupakan teknik pengambilan anggota sampel dari populasi yang dilakukan secara acak tanpa memperhatikan strata yang ada dalam populasi tersebut.

Tes yang digunakan dalam penelitian ini berupa tes untuk penguasaan Shiekibun mahasiswa tahun masuk 2017. Bentuk tes yang digunakan dalam penelitian ini adalah tipe tulisan berbentuk objektif. Dalam penelitian ini tes yang diberikan adalah pilihan ganda.

Langkah pertama, mengubah skor menjadi nilai. Kedua, menafsirkan penguasaan Shiekibun. Ketiga, mengklasifikasikan kemampuan kanoukei mahasiswa tahun masuk 2017 Pendidikan Bahasa Jepang Universitas Negeri Padang berdasarkan penggunaan skala 10 sesuai dengan sebaran nilai Universitas Negeri Padang. Keempat, membahas dan menyimpulkan hasil analisis.

\section{HASIL DAN PEMBAHASAN}

\section{Hasil}

Berdasarkan analisis terhadap skor tes, penguasaan Shiekibun mahasiswa tahun masuk 2017 prodi pendidikan bahasa Jepang Universitas Negeri Padang sebagai berikut. 
Tabel Nilai Rata-Rata Hasil Tes Penguasaan Shiekibun Mahasiswa Tahun Masuk 2017 Prodi Pendidikan Bahasa Jepang Universitas Negeri Padang

\begin{tabular}{|l|c|c|c|c|}
\hline & Nilai Max & Nilai Min & $\begin{array}{c}\text { Rata-Rata } \\
\text { (M) }\end{array}$ & Kualifikasi \\
\hline $\begin{array}{l}\text { penguasaan } \\
\text { shiekibun }\end{array}$ & 96 & 44 & 66,8 & Cukup Baik \\
\hline
\end{tabular}

Berdasarkan tabel di atas dapat diketahui nilai rata-rata penguasaan Shiekibun mahasiswa yang diperoleh dari 30 orang mahasiswa adalah 66,8 dengan kualifikasi lebih dari cukup. Nilai tertinggi yang diperoleh mahasiswa adalah 96 dengan kualifikasi dengan pujian dan nilai terendah yang diperoleh mahasiswa adalah 44 dengan kurang.

\section{Pembahasan}

Sebagaimana telah dideskripsikan, hasil analisis data menunjukan secara keseluruhan kemampuan penggunaan Shiekibun mahasiswa tahun masuk 2017 prodi pendidikan bahasa Jepang Universitas Negeri Padang dengan nilai rata-rata 66,4 dengan prediket 'Cukup Baik'. Jika nilai rata-rata tersebut dibandingkan dengan nilai mutu mata pelajaran yang telah ditetapkan Oleh pihak kampus Universitas Negeri Padang, maka mahasiswa mendapatkan nilai B- dengan nilai rata-rata tersebut.

Dalam penelitian ini, dapat diketahui pemhaman Shiekibun pada mahasiswa dari tiga jenis indikator yang dinilai. Indikator tersebut adalah (1) Mahasiswa mampu mengubah kata kerja ke bentuk Shieki, (2) Mahasiswa mampu menggunakan partikel pada Shieki, (3) Mahasiswa mampu menggunakan Shiekibun. Dalam penelitian ini diketahui tiga hal sebagai berikut.

Pertama, pemahaman Shiekibun mahasiswa tahun masuk 2017 prodi pendidikan bahasa Jepang Universitas Negeri Padang untuk indikator I (mahasiswa mampu mengubah kata kerja ke bentuk Shieki) dengan nilai rata-rata 82 dengan predikat 'Sangat Baik Sekali'. Nilai tertinggi yang diperoleh siswa adalah 100. Dari nilai tersebut diketahui bahwa mahasiswa tersebut menguasai penggunaan Shieki dengan baik. Sementara nilai terendah yang diperoleh mahasiswa adalah 50. Diketahui bahwa mahasiswa belum menguasai penggunaan Shikei dengan baik, dilihat dari jawaban mahasiswa dimana kosakata kata kerja yang seharusnya mengandung bentuk Shieki akan tetapi mahasiswa tersebut memilih jawaban yang penggunaan Shieki yang salah dan tidak mengandung penggunaan Shieki yang benar. Sampel kurang teliti dalam memilih jawaban yang tepat.

Menurut pendapat penelitian sebelumnya mengenai kalimat Shieki Mangeronkonda (2013) dalam skripsinya mengatakan bahwa kesalahan mahasiswa dalam pembelajaran kalimat Shieki tentang pembahasan partikel disimpulkan bahwa kesalahan dalam menentukan subjek/pelaku pada kalimat Shieki dalam kalimat bahasa Jepang dan penyebab terjadi kesalahan karena pembelajar tidak sering memakai atau membuat kalimat dalam kata kerja Shieki.

Kedua, untuk indikator II (mahasiswa mampu menggunakan partikel pada Shieki) dengan nilai rata-rata 57,33 dengan predikat 'Cukup'. Nilai tertinggi yang 
diperoleh mahasiswa adalah 90. Sementara nilai terendah yang diperoleh mahasiswa adalah 20. Untuk mahasiswa yang mendapat nilai terendah pada indikator ini disebabkan karena tidak teliti dalam memilih jawaban dengan baik, mahasiswa bisa membaca pernyataan soal yang mengandung Shieki, namun tidak bisa menggunakan partikel dalam bahasa Jepang apabila telah digabungkan dengan kalimat dalam kata kerja bentuk Shieki. Dan dominan sampel sering tertukar pada penggunaan partikel をdan が.

Menurut pendapat penelitian sebelumnya Norman (2011) dalam skripsinya mengatakan bahwa kesalahan mahasiswa dalam pembelajaran kalimat Shieki disebabkan karna ; 1) Partikel yang digunakan masih binggung dengan penggunaan $N i$ (に) dan Wo (を). 2) responden menganggap beberapa kalimat alam soal merupakan bentuk perintah pasif, aktif atau perintah. 3) pengajar tidak menjelaskan secara terperinci dan kurang diberi latihan.

Ketiga, untuk indikator III (mahasiswa mampu menggunakan Shiekibun) dengan nilai rata-rata 56,67 dengan predikat 'Cukup'. Nilai tertinggi yang diperoleh mahasiswa adalah 100. Sementara nilai terendah yang diperoleh mahasiswa adalah 20. Nilai rendah yang diperoleh mahasiswa pada indikator ini yaitu dikarenakan mahasiswa salah memahami penggunaan Shieki. Dan dominan salah mengubah kata kerja bentuk Shieki kata kerja golongan I dan II mereka binggung kata kerja golongan berapa pada butir soal.

Hidayah (2015) menyimpulkan dalam skripsinya bahwa kesalahan dalam menggunakan Shiekibun dikarenakan; 1) responden tidak mengetahui hubungan antara kata benda dengan kata kerja pada kalimat Shieki. 2) terpengaruh makna kalimat dalam bahasa ibu. 3) keliru dalam membedakan kata kerja golongan I, II, dan III.

Berdasarkan pembahasan diatas bahwa pemahaman Shiekibun pada mahasiswa tahun masuk 2017 prodi pendidikan bahasa Jepang Universitas Negeri Padang secara umum kurang cukup memahami penggunaan Shieki. Masih banyak juga yang masih belum menguasai Shieki.

\section{KESIMPULAN}

Penelitian ini difokuskan untuk mengetahui pemahaman Shiekibun mahasiswa tahun masuk 2017 prodi pendidikan bahasa Jepang Universitas Negeri Padang. Diketahui berdasarkan tiga indikator. Indikator tersebut adalah (1) Mahasiswa mampu mengubah kata kerja ke bentuk Shiekibun, (2) Mahasiswa mampu menggunakan partikel pada Shieki, (3) Mahasiswa mampu menggunakan Shiekibun.

Berdasarkan hasil analis data yang telah diuraikan pada bab IV, dapat disimpulkan empat hal sebagai berikut. Pertama, pemahaman Shiekibun untuk mahasiswa tahun masuk 2017 prodi pendidikan bahasa Jepang Universitas Negeri Padang dengan nilai rata-rata 66,11. Kedua, dari ketiga indikator yang telah diujikan, dapat disimpulkan bahwa pemahaman Shiekibun untuk mahasiswa yang terkuat terdapat pada indikator mahasiswa mampu mengubah kata kerja ke bentuk Shieki dengan nilai rata-rata 82, sedangkan yang terlemah terdapat pada indikator mahasiswa mampu menggunakan partikel pada Shieki dengan nilai rata-rata 57,33. Ketiga, kebanyakan mahasiswa memiliki kendala dalam menggunakan Shieki. Keempat, sebagia besar mahasiswa masih belum memahami penggunaan Shieki 
dengan baik, dan kurang pengunaan dan berlatih dalam menggunakan kalimat Shieki.

\section{REFERENSI}

Arikunto, S. 2002. Metodologi Penelitian. Jakarta : PT. Rineka Cipta.

Buji, Kitsu Kawa. 1989. Nihongo Bunkei Jiten. Japan : Honsha

Dahidi, Ahmad dan Sudjianto. 2007. Pengantar Linguisik Bahasa Jepang. Jakarta : Kesaint Blanc.

Dahidi, Ahmad dan Sudjianto. 2009. Pengantar Linguistik Bahasa Jepang. Jakarta : Oriental.

Djiwandono, Soenardi. 2008. Tes Bahasa Pegangan Bagi Bahasa Jepang. Jakarta : Indeks.

Etsuko, T dan Masako. W. 2004. Shokyuu Nihongo Bunpou Sou Matome 20 Pointo . Tokyo : 3A Corporation

Hardianti, Putri. 2019. “ Kemampuan Sonkeigo Dan Kenjougo Mahasiswa Semester VI Tahun Masuk 2016 Program Studi Pendidikan Bahasa Jepang Universitas Negeri Padang “ Jurnal Omiyage. Padang: Universitas Negeri Padang

Hidayah, Lailatun Nurul. 2015. “Analisis Kesalahan Penggunaan Ukemi, Shieki, dan Shieki Ukemi Dalam Kalimat Bahasa Jepang”. Skripsi. Universitas Negeri Semarang, Semarang.

Januardi, Abrar. 2017. “Kemampuan Penggunaan Jootai no Fukushi Mahasiswa Program Studi Pendidikan Bahasa Jepang Universitas Negeri Padang Tahun Masuk 2014”. Skripsi. Universitas Negeri Padang, Padang.

Khaer, ummul. 2014. "analisis kesalahan mahasiswa dalam menggunakan kalimat kausatif-pasif bahasa jepang (shieki-ukemi bun)”. Jurnal. Universitas Pendidikan Indonesia. Hlm. 2.

Koyama. (2001). Minna no Nihongo II. (みんなの日本語) (Terjemahan \& Keterangan Tata Bahasa). Tokyo: Suri-e-nettowa-ku.

Mangerongkonda, Ivond. 2013. Analisis Kesalahan Penggunaan Kata Kerja Kausatif (Shieki Doushi) dalam Kalimat Bahasa Jepang. Skripsi. Universitas Negeri Semarang, Semarang.

Matsumura, Yamaguchi. 1998. Kokugo Jiten. Tokyo : Obunsha 
Matsuoka, Hiroshi (Ed.). 2000. Shokyû o Oshieru Hito no Tame no Nihongo Bunpō Handobukku. Tokyo : 3A Corporation.

Norman, Yusuf. "Analisis Kesalahan Penggunaan Shieki Pada Mahasiswa Program Studi S1 Sastra Jepang Angkatan 2011 Universitas Brawijaya”. Skripsi. Universitas Brawijaya, Malang.

Rohman, Yanuar Lutfi. 2015. "Efektivitas Metode Coopeative Learning Reciprocal Teaching Dalam Pembelajaran Sakubun”. Jurnal. Universitas Pendidikan Indonesia. HIm. 8.

Satini, Ria. 2016. "Kemampuan Menulis Karangan Eksposisi dengan Menggunakan Teknik Mind MapSiswa Kelas X SMAN 14 PADANG'. (Jurnal). Padang: STKIP PGRI

Satini, Ria. 2016. "Kemampuan Menulis Karangan Eksposisi dengan Menggunakan Teknin Mind MapSiswa Kelas X SMAN 14 Padang”. Jurnal. Padang : STKIP PGRI

Sugiyono. 2009. Metode Penelitian Pendidikan. Bandung : Afabeta.

Sugiyono. 2013. Metode Penelitian Pendidikan Pendekatan Kuantitatif Kualitatif dan $R \& D$. Bandung : Alfabeta.

Sutedi, Dedi. 2007. Nihongo no Bunpou. Bandung : Humaniora.

Sutedi, Dedi. 2009. Penelitian Pendidikan Bahasa Jepang. Bandung : Humaniora.

Thama, Andri Dwi. 2014. "Kemampuan Membaca Pemahaman Siswa Kelas VII SMPN 1 KERKAP Berdasarkan Taksonomi Barret Tahun Ajaran 2013/2014”. (Jurnal). Bengkulu: Universitas Negeri Bengkulu.

Zalman, Hendri. 2014. Kosakata Bahasa Jepang Dasar. Padang : FBS UNP Press. 